\title{
ЭКСПЕРИМЕНТАЛЬНОЕ ИССЛЕДОВАНИЕ ПУЛЬСАЦИОННЫХ ХАРАКТЕРИСТИК ЗАКРУЧЕННОГО ПОТОКА В МОДЕЛИ ЧЕТЫРЕХВИХРЕВОЙ ТОПКИ
}

\author{
Шадрин Евгений Юрьевич', \\ evgen_zavita@mail.ru
}

\author{
Ануфриев Игорь Сергеевич', \\ anufriev@itp.nsc.ru
}

\author{
Глушков Дмитрий Олегович', \\ dmitriyog@tpu.ru
Институт теплофизики им. С.С. Кутателадзе СО РАН, Россия, 630090, г. Новосибирск, пр. Академика Лаврентьева, 1.
2 Национальный исследовательский Томский политехнический университет, \\ Россия, 634050, г. Томск, пр. Ленина, 30.
}

\begin{abstract}
Актуальность исследования обусловлена необходимостью вовлечения в топливно-сырьевую базу низкосортных высокозольных углей в связи с ограниченностью запасов высококачественного топлива. Для их эффективного и экологически безопасного использования требуется разработка новых и модернизация имеющихся котельных агрегатов с предварительным физическим и численным моделированием.

Целью работы является экспериментальное исследование пульсационных характеристик турбулентного закрученного потока в модели перспективного топочного устройства, использующего четырёхвихревую схему сжигания пылеугольного топлива.

объектом исследования является изотермическая лабораторная модель четырёхвихревой топки, выполненная из оптически прозрачного оргстекла для проведения измерений в рамках современных бесконтактных методов диагностики потоков.

Методы: физическое лабораторное моделирование аэродинамики и процессов переноса в четырехвихревой топке; бесконтактное исследование осредненных и пульсационных характеристик в объеме модели топки при различных режимных параметрах; исследование пульсаций давления с использованием конденсаторного микрофона.

Результаты. С использованием метода цифровой трассерной визуализации получены распределения осредненных и пульсационных характеристик скорости потока в ряде сечений модели в широком диапазоне режимных параметров. Определено положение зон с высоким значением турбулентных пульсаций и застойных зон, установлены особенности их расположения в зависимости от режимов. С использованием конденсаторного микрофона получены данные о пульсациях давления в локальных областях объема модели. Анализ спектральных характеристик с применением к полученным данным преобразования Фурье показал, что в изучаемой модели отсутствуют нестационарные периодические колебания, связанные с прецессией вихревого ядра потока. Измеренные пульсации давления вызваны акустикой, пульсации скорости носят случайный характер и не связаны с динамикой когерентных структур.
\end{abstract}

\section{Ключевые слова:}

Четырехвихревая топка, процессы переноса, турбулентные пульсации, спектральные характеристики, цифровая трассерная визуализация.

\section{Введение}

Органическое топливо, такое как каменный уголь, остается одним из основных источников получения электрической и тепловой энергии. Однако самая современная электростанция в России построена в прошлом веке. В связи с чем актуальной задачей является разработка нового оборудования, обеспечивающего высокие технико-экономические показатели при соответствии действующим экологическим нормативам, регламентирующим выбросы в окружающую среду таких отходов, как: летучая зола, оксиды серы и азота, других токсичных продуктов сгорания. Одной из перспективных технологий в данном направлении является факельное сжигание пылеугольной смеси в вихревом потоке [1-7]. Закрутка потока позволяет решить ряд задач: увеличить время пребывания топливных частиц в камере сгорания, что снижает механический недожог; уменьшить количество вредных выбросов до удовлетворяющего экологиче- ским нормам уровня за счет понижения температуры в области горения; упростить конструкцию котла и снизить затраты на изготовление; обеспечить дополнительные возможности управления процессом сжигания топлива.

Вихревые технологии реализуются в различных типах топочных устройств, среди которых можно выделить: топку с пересекающимися струями (МЭИ), полуоткрытую топку с встречно-наклонным расположением горелок (ВТИ), вихревую топку с горизонтальной осью закрученного потока (ЦКТИ), низкотемпературную вихревую топку (ЛПИ) и др. Каждая из конструкций обладает своими преимуществами и недостатками, которые обычно выявляются только на стадии полномасштабных стендовых испытаний или опытно-промышленной эксплуатации. В настоящей работе исследуется перспективная конструкция четырёхвихревой топки пылеугольного котла, работающего на высокозольном угольном топливе (шлакую- 
щийся бурый уголь). Такая схема сжигания пылеугольного топлива с диагональной компоновкой горелок была разработана СибВТИ для реконструкции группы котлов на территории Красноярского края. Перспективы применения четырехвихревой схемы сжигания связаны с отсутствием огромных затрат при реконструкции типовых котлов. Опыт эксплуатации показал, что сжигание высокозольных углей может приводить к интенсивному шлакованию топки и пароперегревателя, в результате чего котлы несут пониженную нагрузку. Оценка эффективности реконструкции котлов выявила ряд недостатков в работе котла, требующих дальнейшей его модернизации. Для повышения технико-экономических и экологических показателей необходима оптимизация режимных и конструктивных параметров четырёхвихревой топки пылеугольного котла, требующая выполнения комплекса НИР.

Известно, что оптимальная организация аэродинамики течения в топке обеспечивает основу для эффективного процесса сжигания, отвечающего заданным технологическим требованиям. Важной проблемой при этом является предотвращение возникновения нежелательных нестационарных явлений, таких как прецессия вихревого ядра потока, способных негативно влиять на процесс сжигания топлива и эксплуатации котла в целом. В настоящей работе экспериментально исследованы пульсационные характеристики потока в лабораторной изотермической модели (рис. 1, б) четырёхвихревой топки пылеугольного котла [8]. Топка оборудована прямоугольной экранированной камерой сгорания. На боковых стенках установлены по два диагонально направленных блока многоярусных горелок. На фронтовых и тыловых стенках по центру расположены сопла вторичного дутья, выполненные в виде вертикальных пристенных щелей, равных по высоте горелочному блоку и ориентированных относительно друг друга в противоположные стороны вдоль стен, на которых они расположены. Расположение боковых горелок обеспечивает эффективное взаимодействие, смесеобразование и воспламенение горелочных струй за счет интенсивного подсоса топочных газов в межгорелочное пространство. Система сопел вторичного дутья необходима для формирования четырехвихревой аэродинамики, снижения выбросов $\mathrm{NO}_{x}$ и защиты экранов от шлакования. Отличием исследуемой модели от ранее изученной [9] является наличие на тыльной стенке сопел подачи пылеугольной смеси (вместо сопел подачи третичного воздуха), симметричных соплам, установленным на фронтальной стенке.

\section{Экспериментальный стенд и методика измерений}

Модель изготовлена из оптически прозрачного оргстекла толщиной 10 мм в масштабе 1:25 (внутренние размеры $290 \times 880 \times 730 \mathrm{~mm})$. На боковых стенках в три яруса расположены по два диагонально направленных сопла под углом $6^{\circ}$ (размеры $28 \times 50$ мм), оси боковых сопел направлены к центру топки. На фронтальной и задней стенке установлены также в три яруса (на отметках расположения боковых сопел) по два центральных сопла (размеры сопел $23 \times 66$ мм), направленных в сторону боковых стенок под углом $20^{\circ}$.

Исследования проводились на экспериментальном стенде, основными элементами которого являются (рис. 2): автоматизированный комплекс регулирования и подачи сжатого воздуха; изотермическая лабораторная модель четырёхвихревой топки; контролирующие приборы. Стенд подключен к сети подачи сжатого воздуха и системе вентиля-
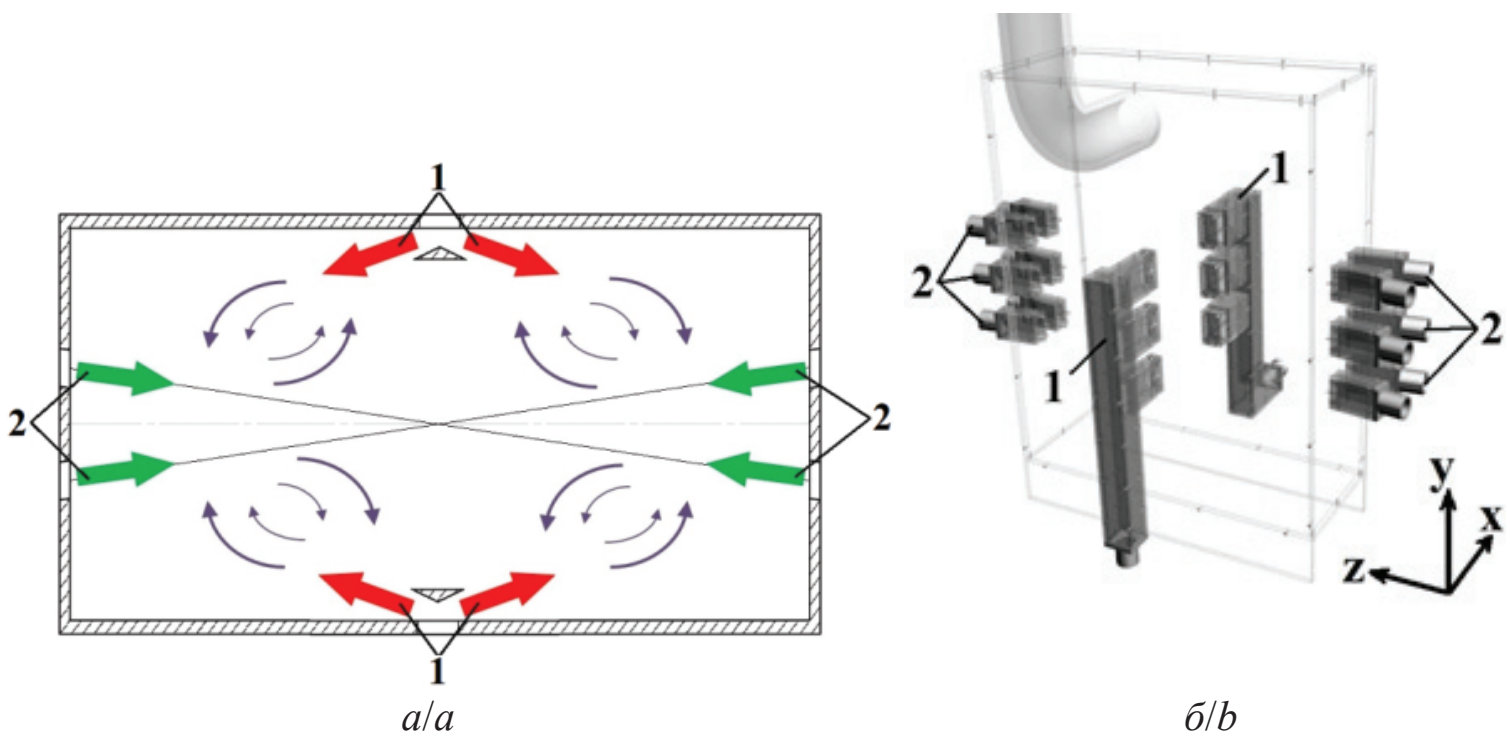

Pис. 1. Четырехвихревая схема сжигания угольного топлива (а); схема лабораторной модели четырехвихревой топки (б); 1 центральные сопла; 2 - боковые сопла

Fig. 1. Four-vortex scheme for coal fuel combustion (a); scheme of the four-vortex furnace laboratory model (b): 1 are the central nozzles; 2 are the side nozzles 
ции, оснащен устройством засева потока трассерами - микрокаплями растительного масла, генерируемого с использованием сопла Ласкина.

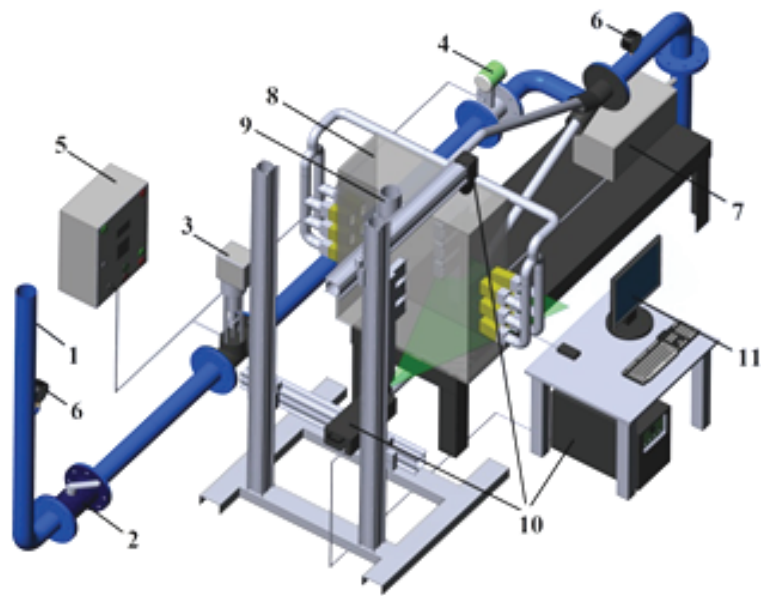

Рис. 2. Схема экспериментального стенда с четырехвихревой топкой: 1 - магистраль подачи сжатого воздуха 2 - запорный кран, 3 - запорно-регулирующий клапан с электроприводом, 4 - преобразователь расхода, 5 - шкаф управления, 6 - манометры, 7- устройство засева потока (сопло Ласкина), 8 - модель четырёхвихревой топки, 9-вентиляция, 10 - PIV-система, 11 - компьютер

Fig. 2. Scheme of the experimental stand with a four-vortex furnace: 1 is the compressed air supply line, 2 is the shut off valve, 3 is the control valve with the electric drive, 4 is the flow converter, 5 is the control cabinet, 6 are the manometers, 7 is the flow seeding device (Laskin nozzle), 8 is the four-vortex furnace model, 9 is the ventilation, 10 is the PIV-system, 11 is the computer

Исследование пульсаций скорости потока в модели четырёхвихревой топки осуществлялось методом цифровой трассерной визуализации (particle image velocimetry, PIV) по методике, аналогичной описанной в работах $[9,10]$. Измерение поля мгновенной скорости потока в заданном сечении основано на измерении перемещения частиц примеси (трассеров), находящихся в плоскости сечения, за фиксированный интервал времени. Определение перемещения основано на применении корреляционных методов к трассерным картинам, с использованием регулярного разбиения на элементарные области.

При проведении экспериментов использовалась PIV-система «Полис», позволяющая измерять две компоненты вектора скорости одновременно во всем исследуемом сечении. Измерительный комплекс включает в себя: двойной импульсный Nd: YAG лазер QuantelEVG с энергией в импульсе 145 мДж, частотой импульсов - до 15 Гц, длительностью импульса - 10 нс; объектив для формирования лазерного ножа; CCD камеру Видеоскан 4021 с разрешением $2048 \times 2048$ пикселей, частотой съемки - до 1,25 Гц, временем экспозиции - 128 мс; широкоугольный объектив Nikon 28 mm F/2.8 D; синхронизирующий процессор; персональный компьютер с программным обеспечением ActualFlow и пакетом PIV Kit; крепежный комплект на основе элементов Newport. Для перемещения измерительной системы использовалось координатно-перемещающее устройство, позволяющее позиционировать измерительную плоскость внутри модели топки с пространственным шагом от 0,1 мм.

Измерения пульсаций скорости проведены в ряде горизонтальных сечений. В каждом сечении регистрировалась серия из 1000 пар кадров с частотой 1,25 Гц. Время задержки между кадрами в паре кадров в зависимости от режима составляло 100-150 мкс. Для обработки данных использовался итерационный кросскорреляционный алгоритм расчёта полей скорости с разбиением расчетной области на ячейки размером $32 \times 32$ пикселей с пространственным перекрытием 50 \%. Для подавления фоновой засветки использовался алгоритм цифровой фильтрации изображения ( «вычитание фона»).

В экспериментах среднерасходная скорость на выходе из сопел выбиралась из следующих соображений. Для реального котла характерна распределенная подача аэросмеси: 14-25 м/с через центральные сопла; 25 м/с через боковые. Лабораторная установка обеспечивает подачу воздуха в модель с максимальным регулируемым расходом до $500 \mathrm{~m}^{3} /$ ч, что соответствует во всех 24 соплах одинаковой скорости $4 \mathrm{~m} / \mathrm{c}$. Тем самым были проведены измерения в широком диапазоне соотношений расходов через центральные и боковые сопла: от 1 и $3 \mathrm{~m} / \mathrm{c}$ до 4 и $4 \mathrm{M} / \mathrm{c}$, соответственно. Число Рейнольдса по длине камеры сгорания составляет $\operatorname{Re} \approx 2 \times 10^{5}$, это обеспечивает автомодельность течения. Регулировка потоков через центральные и боковые сопла осуществлялась с помощью заслонки и установленного за ней расходомера.

Измерения пульсаций давления выполнены анализатором шума Bruel\&Kjaer 2250: давление до 103,5 кПа, частота измерений 4 Гц-20 кГц, чувствительность 54,9 мВ/Па; аналогично [11, 12]. Датчик помещался в измерительный объем при помощи отборника - тонкостенной металлической трубки диаметром 2,2 мм и длиной 160 мм. Передаточная функция отборника представлена в работе [13], где показана его применимость без корректировки до частот 100 Гц. Сигнал обрабатывался с помощью АЦП (L-CARD E14-440). Измерения проводились в двух точках: вблизи условного центра локализации вихревого ядра $(x=240 \mathrm{mм}$, $z=100 \mathrm{mм)}$ и в области с максимальным значением пульсаций скорости ( $x=185$ мм, $z=100$ мм). Измерения выполнялись с частотой 1 кГц в течение 30 с. Исследованы пульсации давления при различных соотношениях расходов.

\section{Результаты}

На рис. 3 представлено векторное поле скорости, полученное методом PIV в горизонтальном сечении, проходящем через центр среднего яруса сопел, и поля пульсаций z-компоненты скорости (рис. $3, a)$ и х-компоненты скорости (рис. 3, б). Измерения проведены в половине исследуемой обла- 
сти с последующим отражением от вертикальной плоскости симметрии, проходящей через середины центральных сопел. Пространственное разрешение для ячейки $32 \times 32$ пикселя составляло 3 мм на вектор в обоих направлениях (на рисунке для наглядности вектора «прорежены» в четыре раза, поэтому пространственный шаг между векторами составляет 12 мм). Серым цветом отмечена «слепая» область, в которой из-за геометрических особенностей модели измерения методом PIV невозможны.

Полученные результаты (рис. 3) демонстрируют сложную структуру течения в исследуемой модели топки, состоящую из четырех сопряженных вихрей. Струи, выходящие из сопел, расположенных на боковых стенках, на расстоянии трех калибров сопла интенсивно перемешиваются, что подтверждается высоким уровнем пульсаций скорости в этой области. На практике это будет иметь важное значение, так как за счет лучшего перемешивания с реагирующим горящим потоком свежей топливно-воздушной смеси обеспечивается её эффективное воспламенение и более полное сжигание. Высокое значение пульсаций скорости также позволяет добиться заполнения топочного пространства реагирующей смесью, тем самым добиться равномерного распределения температуры и тепловых пото-

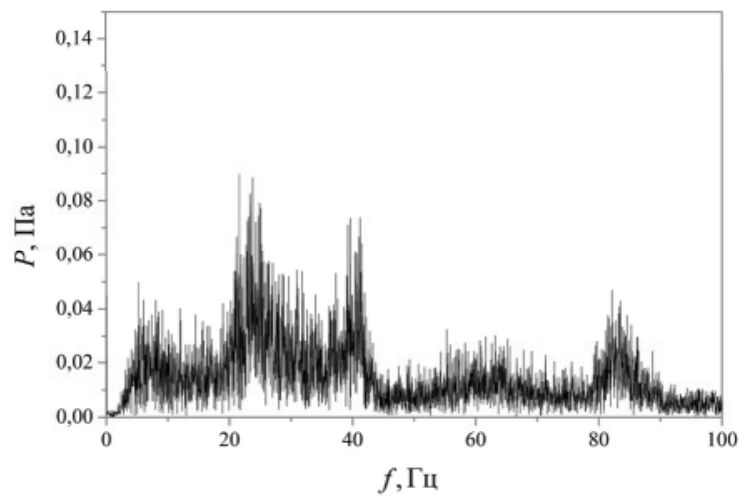

$a / a$

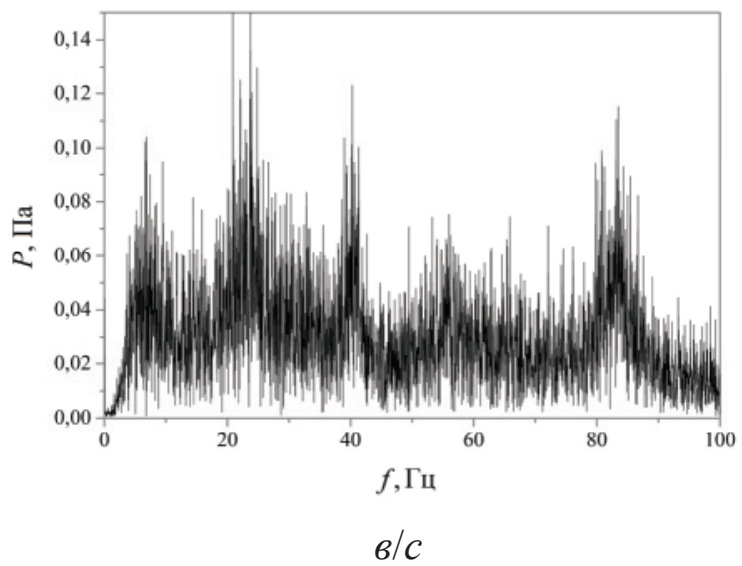

ков во всем объеме топки, понизить среднее значение температуры, тем самым существенно понизить количество вредных выбросов, таких как $\mathrm{NO}_{\text {х }}$.
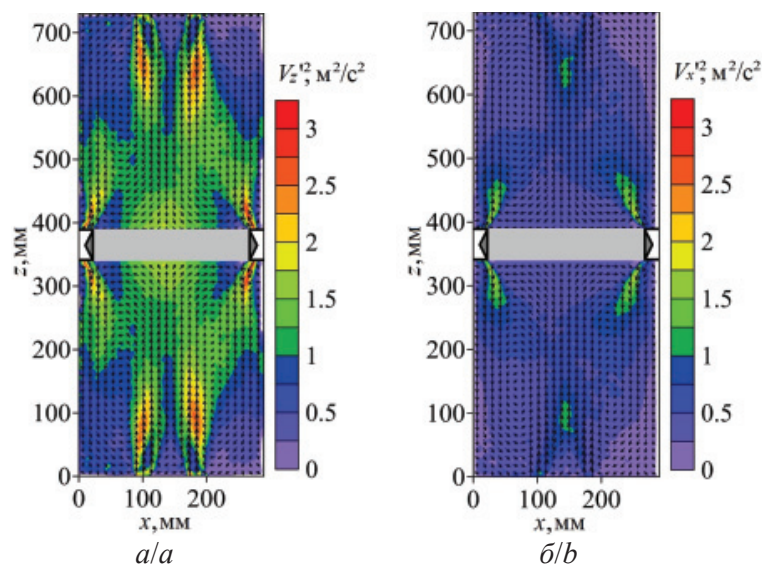

Рис. 3. Распределение пульсаций z-компоненты (а) их-компоненты (б) скорости при среднерасходной скорости 3 и 4 м/с через центральные и боковые сопла, соответственно

Fig. 3. Distribution of pulsations of z-component (a) and $x$ component (b) of the velocity at average velocities of 3 and $4 \mathrm{~m} / \mathrm{s}$ through the central and side nozzles, respectively

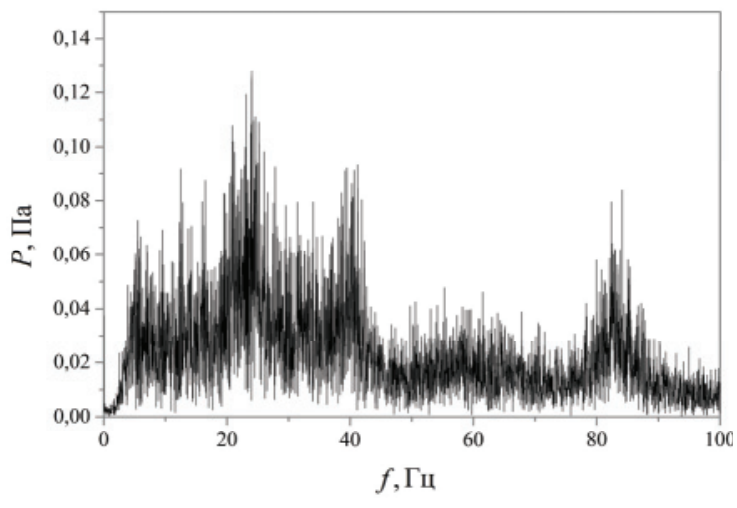

$\sigma / b$

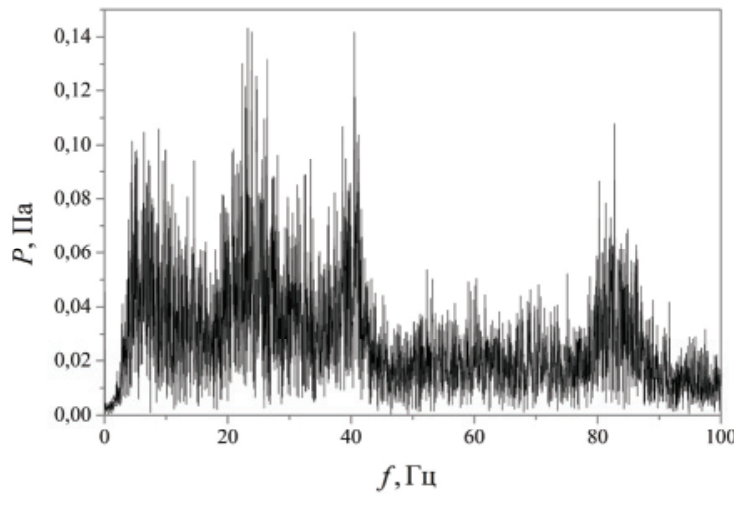

$2 / d$

Pис. 4. Спектры пульсаций давления вблизи условного центра вихревого ядра при различных среднерасходных скоростях через центральные и боковые сопла, соответственно: а) 2 и 4; б) 3 и 4; в) 3 и 5; г) 2 и $6 \mathrm{~m} / \mathrm{c}$

Fig. 4. Pressure pulsations spectra near the center of the vortex core at various average velocities through the central and side nozzles, respectively: a) 2 and 4 ; b) 3 and 4 ;c) 3 and 5; d) 2 and $6 \mathrm{~m} / \mathrm{s}$ 
На рис. 4 представлены спектры пульсаций давления вблизи центра вихревого ядра ( $x=240 \mathrm{Mм}$, $z=100$ мм) в нижнем ярусе для различных режимов. Амплитуда представленных в спектре пиков достаточно мала, а их положение не зависит от расходов, что характеризует эти пики как акустические шумы и резонансы. Тем самым заметных пульсаций давления с частотой, зависящей от расхода, которые могли бы свидетельствовать о наличии в потоке нестационарных когерентных вихревых структур [14] (как, например, в работах [15-17]), не обнаружено.

\section{Заключение}

В широком диапазоне режимных параметров исследованы пульсационные характеристики закрученного потока в модели усовершенствованной четырехвихревой топки с использованием современного бесконтактного метода диагностики

\section{СПИСОК ЛИТЕРАТУРЫ}

1. Практика и перспективы применения различных способов сжигания твердого топлива в теплоэнергетических установках М.Н. Башкова, С.А. Казимиров, М.В. Темлянцев, В.И. Багрянцев, А.А. Рыбушкин, К.С. Слажнева // Вестник СибГИУ. 2014. - № 2 (8). - C. 24-32.

2. Разработка агрегата и технологии для эффективного сжигания дисперсных отходов углеобогащения во вращающемся потоке воздуха / В.И. Багрянцев, С.А. Бровченко, А.П. Подольский, А.А. Рыбушкин, М.В. Темлянцев, С.А. Казимиров // Вестник СибГИУ. - 2013. - № 4. - С. 36-41.

3. Krasinsky D.V., Sharypov 0.V. Numerical modeling of pulverized coal combustion in the vortex furnace with dual upper-port loading // Journal of Engineering Thermophysics. - 2015. V. 24. - № 4. - P. 348-356.

4. Krasinsky D.V. Numerical modelling of the flow and combustion processes in coal-fired vortex furnace // International Review of Mechanical Engineering. - 2015. - V. 9. - № 5. - P. 507-516.

5. Исследование процессов горения искусственного композитного жидкого топлива в циклонном предтопке / А.И. Цепенок, Ю.В. Овчинников, Ю.В. Стрижко, С.В. Луценко // Энергетик. - 2011. - № 7. - С. 45-47.

6. Щуренко В.П., Пузырев Е.М., Сеначин П.К. Моделирование и разработка низкотемпературных вихревых топочных устройств // Ползуновский вестник. - 2004. - № 1. C. $152-156$.

7. Гравитационно-рециркуляционная вихревая топка для сжигания высокозольного топлива / Ю.О. Петрик, П.Т. Афанасьев, А.Р. Богомолов, Г.С. Козлова, П.В. Дадонов // Вестник КузГТУ. - 2009. - № 2. URL: https://cyberleninka.ru/article/n/gravitatsionno-retsirkulyatsionnaya-vihrevaya-topka-dlyaszhiganiya-vysokozolnogo-topliva (дата обращения: 28.02.2018).

8. Призматическая экранированная топка: пат. РФ № 2032853 ; заявл. 01.09.1992; опубл. 10.04.1995.

9. Исследование структуры потока в модели четырехвихревой топки / И.С. Ануфриев, О.В. Шарыпов, А.А. Дектерев, Е.Ю. Шадрин, А.П. Папулов // Теплофизика и аэромеханика. - 2017. - T. 24. - № 6. - C. 873-879.

10. Particle image velocimetry measurement of jet impingement in a cylindrical chamber with a heated rotating disk / Y.-H. Liu, L.-W. Tseng, C.-Y. Huang, K.-L. Lin, C.-C. Chen // Int. J. Heat and Mass Transfer. - 2013. - V. 65. - P. 339-347.

11. Диагностика пространственной структуры закрученного потока в модели вихревой топки / Ю.А. Аникин, И.С. Ануфриев, потоков (PIV) и анализатора пульсаций давления. Проанализирована структура потока, содержащая четыре сопряженных вихря. Показано наличие локальных зон с повышенным уровнем турбулентных пульсаций скорости. Результаты исследований пульсаций давления позволяют сделать вывод об отсутствии нестационарных когерентных структур, что также является положительным свойством исследуемой модели вихревой топки, для которой не характерна прецессия вихревого ядра. Полученные экспериментальные данные могут быть использованы для верификации математических моделей, применяемых при численных расчетах процессов тепло- и массопереноса в полномасштабном котельном оборудовании $[6,7,17-21]$.

Исследования выполнены при финансовой поддержке РФФИ (проект № 17-308-50016 мол нр) и Стипендии президента (СП-400.2018.1).

Е.Ю. Шадрин, О.В. Шарыпов // Теплофизика и аэромеханика. - 2014. - Т. 21. - № 6. - С. 807-810.

12. The analysis of flow stability in a vortex furnace model / I.S. Anufriev, D.0. Glushkov, A.P. Papulov, E.Yu. Shadrin // MATEC Web of Conferences. - 2016. - V. 92. - Article number 01059 .

13. Experimental study and analytical reconstruction of precessing vortex in a tangential swirler / I.V. Litvinov, S.I. Shtork, P.A. Kuibin, S.V. Alekseenko, K. Hanjalic // Int. J. Heat and Fluid Flow. - 2013. - V. 42. - P. 251-264.

14. Alekseenko S.V., Kuibin P.A., Okulov V.L. Theory of Concentrated Vortices: An Introduction. - Springer, 2007. - 494 p.

15. Алексеенко С.В., Шторк С.И., Юсупов Р.Р. Изотермическое моделирование аэродинамической структуры закрученного течения в двухступенчатом горелочном устройстве // Известия Томского политехнического университета. Инжиниринг георесурсов. - 2017. - Т. 328. - № 7. - С. 6-18.

16. Литвинов И.В., Шторк С.И., Алексеенко С.В. Экспериментальное исследование сильнозакрученного течения в тангенциальном завихрителе // Вестник КузГТУ. - 2012. - № 3 (91). C. $129-135$.

17. Fernandes E.C., Heitor M.V., Shtork S.I. An analysis of unsteady highly turbulent swirling flow in a model vortex combustor / Experiments in Fluids. - 2006. - V. 40. - P. 177-187.

18. Trinchenko A., Paramonov A. Low-temperature swirl burning as technological method of simultaneous decrease in emissions of nitrogen and sulfur oxides (Part 1. Principles, organization and mathematical model of furnace process) // Advances in Intelligent Systems and Computing. - 2018. - № 692. - P. 1074-1082.

19. CFD simulation of the combustion process of the low-emission vortex boiler / A.A. Chernov, P.A. Maryandyshev, E.V. Pankratov, V.K. Lubov // Journal of Physics: Conference Series. 2017. - V. 891. - Article number 012216.

20. Сравнительный анализ влияния моделей турбулентности на описание процессов горения угольной пыли при наличии закрутки потока / М.Ю. Чернецкий, В.А. Кузнецов, А.А. Дектерев, Н.А. Абаимов, А.Ф. Рыжков // Теплофизика и аэромеханика. - 2016. - Т. 23. - № 4. - С. 615-626.

21. Paik J., Sotiropoulos F. Numerical simulation of strongly swirling turbulent flows through an abrupt expansion // Int. J. Heat and Fluid Flow. - 2010. - V. 31. - P. 390-400.

Поступила 03.05.2018 г. 
Информация об авторах

Шадрин E.Ю., аспирант, инженер-исследователь Института теплофизики им. С.С. Кутателадзе СО РАН.

Ануфриев И.С., кандидат физико-математических наук, старший научный сотрудник Института теплофизики им. С.С. Кутателадзе СО РАН.

Глушков Д.О., кандидат физико-математических наук, доцент Исследовательской школы физики высокоэнергетических процессов Национального исследовательского Томского политехнического университета. 


\title{
EXPERIMENTAL INVESTIGATION OF PULSATION CHARACTERISTICS OF A SWIRLED FLOW IN A FOUR-VORTEX FURNACE MODEL
}

\author{
Evgeniy Yu. Shadrin', \\ evgen_zavita@mail.ru \\ Igor S. Anufriev', \\ anufriev@itp.nsc.ru \\ Dmitrii O. Glushkov², \\ dmitriyog@tpu.ru
${ }^{1}$ Kutateladze Institute of Thermophysics SB RAS, 1, Lavrentiev Avenue, Novosibirsk, 630090, Russia.
2 National Research Tomsk Polytechnic University, 30, Lenin Avenue, Tomsk, 634050, Russia.

\begin{abstract}
The relevance of research is conditioned by the need to involve low-grade high-ash coals in the fuel and raw materials base due to the limited reserves of high-quality fuel. For their effective and environmentally safe use, it is necessary to develop new and modernize existing boiler units with preliminary physical and numerical modeling.

The aim of this work is an experimental study of the pulsation characteristics of a turbulent swirled flow in the model of a perspective combustion device using a four-vortex combustion scheme for pulverized-coal fuel.

The object of the research is an isothermal laboratory model of the four-vortex furnace made of optically transparent Plexiglas for measurements within the framework of modern non-contact methods for flow diagnostics.

Research methods: physical laboratory modeling of aerodynamics and transport processes in the four-vortex furnace; non-contact study of averaged and pulsation characteristics in the furnace volume at different operating parameters; study of pressure pulsations using a condenser microphone.

Results. Using the method of particle image velocimetry the authors have obtained the distributions of the averaged and pulsation characteristics of the flow velocity in a number of sections of the model over a wide range of regime parameters. The authors determined the location of the areas with high values of turbulent pulsations and stagnant zones, and identified its features depending on the regimes. Information on the pressure pulsations in the localities of the model volume was obtained with the use of a condenser microphone. Analysis of spectral characteristics with applying the Fourier transform to the obtained data shown that there are no non-stationary periodic oscillations due to the vortex core precession in the studied model. The measured pressure pulsations are caused by acoustics, and velocity pulsations are random and are not associated with the dynamics of coherent structures.
\end{abstract}

Key words:

Four-vortex furnace, transport processes, turbulent pulsations, spectral characteristics, particle image velocimetry.

The study was carried out with the financial support of the RFBR (project No.17-308-50016_mol_nr) and the President's Scholarship (SP-400.2018.1).

\section{REFERENCES}

1. Bashkova M.N., Kazimirov C.A., Temlyantsev M.V., Bagryantsev V.I., Rybushkin A.A., Slazhneva K.S. Practice and perspectives of different methods of solid fuel combustion in thermal power plants. Vestnik SibGIU, 2014, no. 2 (8), pp. 24-32. In Rus.

2. Bagryantsev V.I., Brovchenko S.A., Podolsky A.P., Rybushkin A.A., Temlyantsev M.V., Kazimirov S.A. Development of the device and technology for efficient combustion of waste coal dispersed in rotating flow. Vestnik SibGIU, 2013, no. 4, pp. 36-41. In Rus.

3. Krasinsky D.V., Sharypov 0.V. Numerical modeling of pulverized coal combustion in the vortex furnace with dual upper-port loading. Journal of Engineering Thermophysics, 2015, vol. 24, no. 4, pp. 348-356.

4. Krasinsky D.V. Numerical modelling of the flow and combustion processes in coal-fired vortex furnace. International Review of Mechanical Engineering, 2015, vol. 9, no. 5, pp. 507-516.

5. Tsepenok A.I., Ovchinnikov Yu.V., Strizhko Yu.V., Lutsenko S.V. Investigation of combustion processes of artificial composite liquid fuel in a cyclone pre-furnace. Energetik, 2011, no. 7, pp. 45-47. In Rus.
6. Shchurenko V.P., Puzyrev E.M., Senachin P.K. Modeling and development of low-temperature vortex combustion devices. Polzunovskiy vestnik, 2004, no. 1, pp. 152-156. In Rus.

7. Petrik Yu.O., Afanasyev P.T., Bogomolov A.R., Kozlova G.S., Dadonov P.V. Gravitational-recirculating vortex furnace for high-ash fuel combustion. Vestnik KuzGTU, 2009, no. 2. In Rus. Available at: https://cyberleninka.ru/article/n/gravitatsionnoretsirkulyatsionnaya-vihrevaya-topka-dlya-szhiganiya-vysokozolnogo-topliva (accessed 28 February 2018).

8. Srykov S.V., Protsailo M.Ya., Dekterev A.A., Kozlov S.G., Pronin M.S., Kovalevsky A.M., Popov V.P. Prizmaticheskaya ekranirovannaya topka [Prismatic shielded furnace]. Patent RF, no. $2032853,1995$.

9. Anufriev I.S., Sharypov 0.V., Dekterev A.A., Shadrin E.Yu., Papulov A.P. Study of flow structure in a four-vortex furnace model. Thermophysics and Aeromechanics, 2017, vol. 24, no. 6, pp. $849-855$.

10. Liu Y.-H., Tseng L.-W., Huang C.-Y., Lin K.-L., Chen C.-C. Particle image velocimetry measurement of jet impingement in a cylindrical chamber with a heated rotating disk. International Journal of Heat and Mass Transfer, 2013, vol. 65, pp. 339-347. 
11. Anikin Yu.A., Anufriev I.S., Shadrin E.Yu., Sharypov 0.V. Diagnostics of swirl flow spatial structure in a vortex furnace model. Thermophysics and Aeromechanics, 2014, vol. 21, no. 6, pp. 849-855.

12. Anufriev I.S., Glushkov D.0., Papulov A.P., Shadrin E.Yu. The analysis of flow stability in a vortex furnace model. MATEC Web of Conferences, 2016, vol. 92, article number 01059.

13. Litvinov I.V., Shtork S.I., Kuibin P.A., Alekseenko S.V., Hanjalic K. Experimental study and analytical reconstruction of precessing vortex in a tangential swirler. International Journal of Heat and Fluid Flow, 2013, vol. 42, pp. 251-264.

14. Alekseenko S.V., Kuibin P.A., Okulov V.L. Theory of Concentrated Vortices: An Introduction. Springer, 2007. 494 p.

15. Alekseenko S.V., Shtork S.I., Yusupov R.R. Isothermal modeling of swirling flow aerodynamic structure in a two-stage burner. Bulletin of the Tomsk Polytechnic University. Geo Assets Engineering, 2017, vol. 328, no. 7, pp. 6-18. In Rus.

16. Litvinov I.V., Shtork S.I., Alekseenko S.V. Experimental study of a strongly swirled flow in a tangential swirler. Vestnik KuzGTU, 2012, no. 3 (91), pp. 129-135. In Rus.

17. Fernandes E.C., Heitor M.V., Shtork S.I. An analysis of unsteady highly turbulent swirling flow in a model vortex combustor. $E x$ periments in Fluids, 2006, vol. 40, pp. 177-187.

\section{Information about the authors}

Evgeniy Yu. Shadrin, graduate student, research engineer, Kutateladze Institute of Thermophysics SB RAS.

Igor S. Anufriev, Cand. Sc., senior researcher, Kutateladze Institute of Thermophysics SB RAS.

Dmitrii O. Glushkov, Cand. Sc., assistant professor, National Research Tomsk Polytechnic University.
18. Trinchenko A., Paramonov A. Low-temperature swirl burning as technological method of simultaneous decrease in emissions of nitrogen and sulfur oxides (Part 1. Principles, organization and mathematical model of furnace process). Advances in Intelligent Systems and Computing, 2018, no. 692, pp. 1074-1082.

19. Chernov A.A., Maryandyshev P.A., Pankratov E.V., Lubov V.K. CFD simulation of the combustion process of the low-emission vortex boiler. Journal of Physics: Conference Series, 2017, vol. 891, article number 012216.

20. Chernetskiy M.Yu., Kuznetsov V.A., Dekterev A.A., Abaimov N.A., Ryzhkov A.F. Comparative analysis of turbulence model effect on description of the processes of pulverized coal combustion at flow swirl. Thermophysics and Aeromechanics, 2016, vol. 23, no. 4, pp. 591-602. In Rus.

21. Paik J., Sotiropoulos F. Numerical simulation of strongly swirling turbulent flows through an abrupt expansion. International Journal of Heat and Fluid Flow, 2010, vol. 31, pp. 390-400.

Received: 3 May 2018. 